The latest drug to be tried, the xanthine oxidase inhibitor allopurinol, ${ }^{4} 7$ may owe some at least of its effect to the inhibitory principle.

This was not, however, the original rationale for its use. Allopurinol is a well-established drug for uric acid stone disease, since it inhibits the oxidation of xanthine and hypoxanthine to uric acid. Lonsdale ${ }^{8}$ suggested that uric acid or sodium urate crystals could also promote calcium stone formation by providing a substrate for the growth of calcium oxalate crystals (a process called epitaxy). This mechanism was subsequently invoked to explain calcium oxalate crystallisation in very acid urine, ${ }^{9}$ and it was later shown that sodium urate could initiate crystallisation of calcium oxalate from a metastable solution, ${ }^{1011}$ which tended to confirm Lonsdale's theory.

The idea that urinary urate might promote calcium stone disease led to the measurement of urate excretion in calcium oxalate stone-formers. In a small group of patients (perhaps $10^{\circ}{ }_{0}$ of the total) serum or urine urate concentration was above the upper normal limit. ${ }^{5}$ Therapeutic trials of allopurinol were therefore carried out in patients with recurrent calcium stones.

The first convincing results were reported by Coe and Raisen $^{11}: 21$ patients with hyperuricosuria or hyperuricaemia who had had recurrent calcium stones were treated successfully with allopurinol in doses of $150-200 \mathrm{mg}$ daily. This series was later increased to 32 patients, who, having formed 90 stones in 3099 patient-months before treatment, formed only four stones in 819 patient-months during treatment. The difference between the observed and predicted rates was highly significant.

In another study ${ }^{\top}$ allopurinol was compared with a placebo in a double-blind trial in 92 patients, who were followed for periods of six months to five years before the code was broken. Treatment was ineffective in $21^{\circ}{ }_{0}$ of patients given allopurinol and $48^{\circ}{ }^{\circ}$ of patients given the placebo. During the variable period of follow-up $61^{\circ}$, of the allopurinol-treated cases but only $8^{\circ}{ }_{0}$ of the placebo-treated group developed no further stones. In the few patients followed for five years, however, there was some improvement in $75^{\circ}$ o of allopurinol-treated and some $70^{\prime \prime}{ }^{\circ}$ of placebo-treated patients. The authors conclude that the only criterion of success in the treatment of calcium stone disease is total cessation of stone formation. By this criterion, allopurinol was greatly superior to the placebo.

Allopurinol may therefore have a place in treating calcium oxalate stone disease, at least for patients with raised plasma or urinary urate. And on recent evidence even patients with normal uric acid metabolism may benefit, for allopurinol may after all act not by reducing nucleation of calcium oxalate crystals (or not only in this way) but by increasing inhibitory power-it appears that urates tend to neutralise the inhibitors that delay calcium oxalate crystal growth and aggregation. ${ }^{12}{ }^{13}$ Phosphate supplements may also have a dual action in not only reducing urinary calcium but also increasing urinary inhibitory activity, possibly by raising pyrophosphate output. ${ }^{14}$ Thus the good results claimed for both phosphate and allopurinol treatment may have a wider basis than was envisaged by the proponents of these treatments.

${ }^{1}$ Prien, E L, and Frondel, C, fournal of Urology, 1947, 57, 949.

2 Robertson, W G, et al, New England Fournal of Medicine, 1976, 294, 249.

${ }^{3}$ Nordin, B E C, et al, in Rein et Calcium, ed D J Hioco, p 345. Paris, Sandoz, 1972.

4 Yendt, E R, Canadian Medical Association fournal, 1970, 102, 479.

${ }^{5}$ Coe, F L, and Kavalach, A G, New England fournal of Medicine, 1971, 291, 1344.

6 Bernstein, D S, and Newton, R, Lancet, 1966, 2, 1105.

7 Smith, M J V, fournal of Urology, 1977, 117, 690.

${ }^{8}$ Lonsdale, K, Nature (London), 1968, 217, 56.
${ }^{9}$ Robertson, W G, Peacock, M, and Nordin, B E C, Clinical Science, 1971, 40, 365.

1i) Coe, F L, et al, Proceedings of the Society for Experimental Biology and Medicine, 1975, 149, 926.

${ }^{11}$ Coe, F L, and Raisen, L, Lancet, 1973, 1, 129.

12 Smith, L H, Thomas, W C, and Arnaud, C D, in Urinary Calculi, ed L C Delatte, A Rapado, and A Hodgkinson, p 188. Basle, Karger, 1973.

${ }^{13}$ Robertson, W G, Knoles, F, and Peacock, M, in Urolithiasis Research, ed H Fleisch et al, p 331. New York, Plenum, 1976.

${ }^{14}$ Robertson, W G, et al, in Urinary Calculi, ed L C Delatte, A Rapado, and A Hodgkinson, p 302. Basle, Karger, 1973.

\section{Lymphoid blast crisis in chronic myeloid leukaemia}

Most patients with chronic myeloid leukaemia (CML) and a positive test for the Philadelphia chromosome $\left(\mathrm{Ph}^{1}\right)$ undergo a terminal metamorphosis or blast crisis with clinical and haematological abnormalities similar to acute leukaemia. This is usually myeloblastic in nature, but recent reports have drawn attention to a subgroup of patients in whom a variable proportion of the cells in the blast crisis have the features of lymphoblasts. ${ }^{1-4}$ This variant has been termed lymphoblastic transformation or lymphoid blast crisis of CML.

Lymphoid blast crisis may come after an entirely typical chronic phase of the disease or it may present as an acute or subacute leukaemia which is $\mathrm{Ph}^{1}$-positive and has lymphoid blasts or a mixture of myeloid and lymphoid blasts. ${ }^{235}$ This type may legitimately be termed CML presenting in blast crisis without an apparent chronic phase-paralleling the picture in patients presenting with $\mathrm{Ph}^{1}$-positive acute myeloid leukaemia. ${ }^{6}$ Some patients have the clinical and haematological features typical of acute lymphoblastic leukaemia, and, though morphological abnormalities of the myeloid series are sometimes present," the distinguishing feature is the presence of the $\mathrm{Ph}^{1}$ chromosome. Further evidence of the relation between these various forms comes from patients in whom the morphological features change. Patients presenting with mainly lymphoid cells may occasionally evolve a predominantly myeloid picture and vice versa, and a few exceptional patients diagnosed as having $\mathrm{Ph}^{1}$-positive acute lymphoblastic leukaemia have evolved the typical picture of CML. ${ }^{2} 78$

Blast cells from lymphoid blast crisis have now been studied in detail. In Romanovsky preparations and on electron microscopy they have the appearance of lymphoblasts, and they may stain positively with periodic acid Schiff (PAS).$^{3-5}$ They are phenotypically identical to the cells of common acute lymphoblastic leukaemia: they react with specific antisera to acute lymphoblastic leukaemia and have no markers of differentiation into $\mathrm{T}$ or B lymphocytes. ${ }^{9}$ They have raised concentrations of the enzyme terminal deoxynucleotidyl transferase, which is present in high concentrations in acute lymphoblastic leukaemia but not in acute myeloid leukaemia or myeloid blast crisis. ${ }^{9-12}$ The cells have the buoyant density characteristics of lymphoblasts and show no myeloblastic features in marrow culture. ${ }^{13}$

These observations raise basic questions about the cellular origin of CML. One explanation of the findings in lymphoid blast crisis is that CML arises from a common stem cell capable of both myeloid and lymphoid differentiation. ${ }^{19}$ This contrasts with the traditional view, based on the absence of the $\mathrm{Ph}^{1}$ chromosome abnormality in lymphocytes, that it arises from a cell already committed to myeloid differentiation. 
This common stem cell is presumed to be responsible for the establishment of largely self-perpetuating lymphoid stem cell pools that occurs during very early life. Leukaemic transformation of this cell occurring during adult life, however, while able to explain the peculiarities of lymphoid blast crisis, would not be expected to produce any significant number of $\mathrm{Ph}^{1}$-positive lymphocytes.

There are also important clinical implications in the recognition of lymphoid blast crisis. Blast crisis in CML is generally unresponsive to chemotherapy, but lymphoid blast crisis usually responds, sometimes excellently, to combinations incorporating vincristine and prednisolone. ${ }^{3-514}$ Patients with lymphoid blast crisis or $\mathrm{Ph}^{1}$-positive acute lymphoblastic leukaemla must be identified in prospective trials of chemotherapy, as they are unlikely to do as well as patients with $\mathrm{Ph}^{1}$ negative acute lymphoblastic leukaemia, and they respond better than patients with non-lymphoid blast crisis. ${ }^{15}$ Extension to the central nervous system has been reported ${ }^{14-16}$ in lymphoid blast crisis, and Woodruff et al now report at p 1325 two further patients who developed meningeal leukaemia during haematological remission. The increased incidence of this complication in lymphoid blast crisis may be attributed to longer survival, and these patients should probably receive prophylactic therapy, as is customary in acute lymphoblastic leukaemia.

${ }^{1}$ Boggs, D R, Blood, 1974, 44, 449.

2 Janossy, G, et al, British fournal of Haematology, 1976, 34, 179.

3 Peterson, L C, Bloomfield, C D, and Brunning, R D, American fournal of Medicine, 1976, 60, 209.

- Rosenthal S, et al, Blood, 1977, 49, 705.

${ }^{5}$ Beard, M E J, et al, British fournal of Haematology, 1976, 34, 167.

6 Whang-Peng, J, et al, Blood, 1970, 36, 448.

Forman, E N, et al, Blood, 1977, 49, 549.

${ }^{8}$ Blood Cells, 1975, 1, 53.

'Janossy, G, Roberts, M, and Greaves, M F, Lancet, 1976, 2, 1058.

10 McCaffrey, R, et al, New England fournal of Medicine, 1975, 292, 775.

${ }^{11}$ Hoffbrand, A V, et al, Lancet, 1977, 2, 520.

12 Sarin, P S, Anderson, P N, and Gallo, R C, Blood, 1976, 47, 11.

${ }^{13}$ Moore, M A S, Clinics in Haematology, 1977, 6, 97.

${ }^{14}$ Marmont, A M, and Damasio, E E, Acta Haematologica, 1973, 50, 1.

15 Bloomfield, C D, et al, British fournal of Haematology, 1977, 36, 347.

${ }^{16}$ Atkinson, K, et al, Cancer, 1975, 35, 529.

\section{Shadow over Maltese medicine}

Recent events in Malta will have saddened British doctors. Apart from the unique niche that this Mediterranean island fills in Britain's past, the links between British and Maltese medicine are close, with the medical school there modelled on those in the UK, and external examiners visiting from here. The story of the five-month confrontation between $\mathrm{Mr}$ Dom Mintoff's Government and the Medical Association of Malta depends, as recent correspondence in the $B M \mathcal{F}$ has shown (22 October, p 1082; 12 November, p 1285), on the teller. The BMA has had no doubts, firmly supporting its sister association since the dispute started.

As the honorary secretary of the MAM stated in his letter to the BMF: “. . . The current dispute arose... out of disagreement over new legislation affecting newly qualified doctors and the powers of the Medical Council. In protest, the MAM directed its members to take limited action involving outpatient clinics and non-urgent surgical operations, while continuing to provide the necessary cover for emergencies.

"The Maltese Government reacted by ordering a lock out of doctors and specialists from all State hospitals and by importing foreign doctors from Libya, Czechoslovakia, Pakistan, and the Palestine Liberation Organisation to man emergency hospital services. Within a few days punitive legislation was rushed through parliament prohibiting the Maltese doctors and specialists from practising in private hospitals. Further legislation culminated in their dismissal not only from their government posts but also, in some cases, from their university appointments. The latter included the professors of medicine, surgery, and obstetrics and gynaecology."

The World Medical Association at its recent Dublin meeting ${ }^{1}$ discussed the Malta crisis at the request of the BMA delegation. As a result, Dr P A Farrelly, president of the WMA, and $\mathrm{Mr}$ Walpole Lewin, chairman of the WMA Council, visited Malta in an effort to mediate. Their report (p 1368) is a masterpiece of discretion and they must be gravely disappointed at having come so close to success.

While UK doctors have ample experience of arbitrary Government decisions, nothing in the history of the NHS so far can have cast a gloom comparable to the present shadow over Maltese medicine. Final year medical students have been forced to move abroad to complete their exams and other medical students obliged to do routine cleaning chores in the hospital as part of their "training," in line with the Malta Government's ideological concept of student "workers." The standards of the profession are now subject to direct Government interference, with the registration body vulnerable to the whims of politicians. We all know the consequences for the professions of totalitarian regimes. Ironically, Malta, which won its George Cross helping to fight such tyranny, seems to be treading that same dangerous path. But how many people realise that Malta is in the queue for membership of the EEC? Furthermore, if the forecasts of Brussels bureaucrats are borne out, the odds are in favour of Malta's joining the Nine. Whether this unhappy medical episode would have been averted if Malta had already been a member is arguable, but, judged by its behaviour over this one issue, will the island's present Government be a comfortable bedfellow for the other EEC democracies? Brussels may have to think again.

What practical help can British doctors give to their embattled colleagues? Firstly, they can support the appeal launched by Dr J C Cameron, Chairman of BMA Council (10 September, p 708), to help the 40 or so Maltese medical students who have come to Britain to complete their studies. Secondly, they can give moral support to the WMA in any further efforts to mediate in the dispute. Thirdly, they can warn anyone thinking of holidaying or convalescing this winter in Malta's pleasant climate that the medical services there may not quite be what they were. Finally, they might ponder the implications for professional freedom in their own country.

${ }^{1}$ British Medical fournal, 1977, 2, 779.

\section{Schistosomiasis in China}

Schistosomiasis is the only communicable disease in the world whose prevalence is increasing-despite the enormous amount of time, energy, and money being spent on it.

Eggs passed in human urine or stools hatch when they enter water into freely swimming miracidia, which for a few hours only can infect certain fresh-water snails. Cercariae develop in the liver of the snail, and are shed for the rest of its life; in turn, they can infect man, again for only a few hours, 